\title{
Studies in a Murine Granuloma Model of Instilled Carbon Nanotubes: Relevance to Sarcoidosis
}

\author{
Barbara P. Barna, Anagha Malur and Mary Jane Thomassen *
}

Citation: Barna, B.P.; Malur, A.;

Thomassen, M.J. Studies in a Murine Granuloma Model of Instilled Carbon Nanotubes: Relevance to Sarcoidosis. Int. J. Mol. Sci. 2021, 22, 3705.

https://doi.org/10.3390/ijms22073705

Academic Editor: Sergio Arce

Received: 28 January 2021

Accepted: 31 March 2021

Published: 2 April 2021

Publisher's Note: MDPI stays neutral with regard to jurisdictional claims in published maps and institutional affiliations.

Copyright: (c) 2021 by the authors. Licensee MDPI, Basel, Switzerland. This article is an open access article distributed under the terms and conditions of the Creative Commons Attribution (CC BY) license (https:// creativecommons.org/licenses/by/ $4.0 /)$.
Program in Lung Cell Biology and Translational Research, Division of Pulmonary, Critical Care and Sleep Medicine, Department of Medicine, Brody School of Medicine, East Carolina University, Greenville, NC 27834, USA; mutchka@oberlin.net (B.P.B.); malura@ecu.edu (A.M.)

* Correspondence: thomassenm@ecu.edu; Tel.: +1-252-744-1117
Abstract: Poorly soluble environmental antigens, including carbon pollutants, are thought to play a role in the incidence of human sarcoidosis, a chronic inflammatory granulomatous disease of unknown causation. Currently, engineered carbon products such as multiwall carbon nanotubes (MWCNT) are manufactured commercially and have been shown to elicit acute and chronic inflammatory responses in experimental animals, including the production of granulomas or fibrosis. Several years ago, we hypothesized that constructing an experimental model of chronic granulomatosis resembling that associated with sarcoidosis might be achieved by oropharyngeal instillation of MWCNT into mice. This review summarizes the results of our efforts to define mechanisms of granuloma formation and identify potential therapeutic targets for sarcoidosis. Evidence is presented linking findings from the murine MWCNT granuloma model to sarcoidosis pathophysiology. As our goal was to determine what pulmonary inflammatory pathways might be involved, we utilized mice of knock-out (KO) backgrounds which corresponded to deficiencies noted in sarcoidosis patients. A primary example of this approach was to study mice with a myeloid-specific knock-out of the lipid-regulated transcription factor, peroxisome proliferator-activated receptor gamma (PPAR $\gamma$ ) which is strikingly depressed in sarcoidosis. Among the major findings associated with PPAR $\gamma$ KO mice compared to wild-type were: (1) exacerbation of granulomatous and fibrotic histopathology in response to MWCNT; (2) elevation of inflammatory mediators; and (3) pulmonary retention of a potentially antigenic ESAT-6 peptide co-instilled with MWCNT. In line with these data, we also observed that activation of PPAR $\gamma$ in wild-type mice by the PPAR $\gamma$-specific ligand, rosiglitazone, significantly reduced both pulmonary granuloma and inflammatory mediator production. Similarly, recognition of a deficiency of ATP-binding cassette (ABC) lipid transporter ABCG1 in sarcoidosis led us to study MWCNT instillation in myeloid-specific ABCG1 KO mice. As anticipated, ABCG1 deficiency was associated with larger granulomas and increased levels of inflammatory mediators. Finally, a transcriptional survey of alveolar macrophages from MWCNT-instilled wild-type mice and human sarcoidosis patients revealed several common themes. One of the most prominent mediators identified in both human and mouse transcriptomic analyses was MMP12. Studies with MMP12 KO mice revealed similar acute reactions to those in wild-type but at chronic time points where wild-type maintained granulomatous disease, resolution occurred with MMP12 KO mice suggesting MMP12 is necessary for granuloma progression. In conclusion, these studies suggest that the MWCNT granuloma model has relevance to human sarcoidosis study, particularly with respect to immune-specific pathways.

Keywords: granuloma; sarcoidosis; multiwall carbon nanotubes; alveolar macrophages

\section{Background}

Sarcoidosis. Currently, no single definitive cause has been identified for sarcoidosis, an inflammatory granulomatous disease reported to have an incidence of 33.4 cases/year per 100,000 patients in the United States [1]. Diagnosis is established by clinical history, 
biopsy indicating non-caseating granulomas (which can be present in multiple organs), and negative studies for infectious agents [2]. Sarcoidosis is thought to occur as a reaction to poorly soluble environmental antigen(s) which have not yet been identified, with evidence that the disease may have multiple causes [3]. In approximately $90 \%$ of cases, sarcoidosis involves the lung, and up to $30 \%$ of patients may experience spontaneous remission [4]. Observation rather than treatment is favored in patients with minimal symptoms, good organ function, and no inflammation related to granulomas [4]. No biological markers have been established as assisting a definite diagnosis.

The rationale for the construction and study of a carbon nanotube-induced granuloma model of sarcoidosis was based upon numerous epidemiologic studies linking sarcoidosis incidence with environmental carbon exposures. Among the risk factors associated with sarcoidosis are exposures to wood-burning fireplaces or stoves and the occupation of firefighting [5,6]. Sarcoidosis has also been linked with occupational exposures to inorganic particulates and mycobacteria [5]. Dramatic evidence of relatively rapid elevation in sarcoidosis-like granulomatous disease was found in non-firefighting as well as fire-fighting individuals who were exposed to combustion materials released in the September 2001 World Trade Center (WTC) disaster [7-9]. After that catastrophic event caused by a plane striking the WTC building, follow-up studies of combustion products and some 20,000 responders revealed carbon nanotubes of diverse sizes in dust samples as well as within lung tissues of individuals affected with a pulmonary granulomatous disease resembling that of sarcoidosis [8]. Currently, carbon nanotube-based products are in use in several manufacturing fields such as textiles, polymer products, microelectronics, etc. [10]. Other applications of carbon nanotubes to pharmacy and medical products are under study [11].

\section{Development of a Murine Multi-Wall Carbon Nanotube (MWCNT)-Induced Granuloma Model}

The goal of our studies was to establish a chronic in vivo model of granulomatous inflammation mimicking sarcoid pathophysiology. In our model, MWCNT are administered via oropharyngeal instillation as a bolus into wild-type (C57/B16) mice. Initial dosage ranged from 25 to 100 ug with 100 ug providing consistent granuloma formation maintained up to 90 days after instillation [12]. When compared to an aerosol delivery method, retropharyngeal instillation may be superior as it achieves full and uniform delivery, with decreased variability between exposures [13,14]. A comparative study of lung tissue in inhalation versus instillation demonstrated smaller particle size and diminished pulmonary inflammation with inhalation [14]. However, investigations carried out to determine longterm effects of inhalation versus instillation with similar accumulated material burden had similar outcomes with both techniques $[15,16]$. Time course studies in our MWCNT model indicated well-formed granulomas as early as 10 days which persisted till 90 days. Detailed studies were performed at 60 days post-instillation. Gene and protein expression analyses were carried out on bronchoalveolar lavage (BAL) cells from MWCNT-instilled animals versus sham. Additional gene expression data from both granulomatous and non-granulomatous lung tissue were obtained by laser capture microdissection (LCM). Overall, results indicated significant pulmonary granulomatosis at 60 days, persisting up to 90 days with elevated BAL cell and lung tissue expression of granuloma-promoting factors, including interferon-gamma [17], osteopontin [18], matrix metalloproteinase-12 (MMP-12) [19], cell adhesion molecules [20], and elevated CD3+ T lymphocytes [12]. Differences were noted in gene expression levels within the granulomatous region of the lung as compared to the non-granulomatous parts of the lung. This model of an inhaled carbon nanotube-induced granulomatous disease was found to exhibit multiple similarities to sarcoidosis pathophysiology which are detailed in the following sections.

\section{Role of PPAR $\gamma$ in Sarcoidosis}

The transcription factor, peroxisome proliferator-activated receptor gamma (PPAR $\gamma$ ), is part of a subfamily of nuclear receptors with ligand-inducible activity [21]. PPAR $\gamma$ is 
a critical regulator of lipid and glucose metabolism but also exhibits down-regulatory effects on genes linked to inflammatory events [22]. Alveolar macrophages from healthy individuals express constitutively high levels of PPAR $\gamma$, in contrast to macrophages from other parts of the body [23]. Alveolar macrophages are the first line of defense in the lung which is constantly bombarded with environmental insults. PPAR $\gamma$ is usually present as a heterodimer complexed with retinoid $\mathrm{X}$ receptor alpha $(\mathrm{RXR} \alpha)$ and bound to corepressors. With ligand stimulation, corepressor molecules are removed and the ligand, $\operatorname{PPAR} \gamma, \operatorname{RXR} \alpha$, and coactivators form an active complex, binding to PPAR $\gamma$ response elements (PPRE) [24]. Numerous ligands have been identified which can bind and activate PPAR $\gamma$, leading to anti-inflammatory effects [24]. Ligand-bound PPAR $\gamma$ dampens the inflammatory response and is essential for orchestrating the lipid metabolism necessary for pulmonary surfactant processing and maintenance [25]. These activities are crucial for lung homeostasis. Interestingly, alveolar macrophages from macrophage-specific PPAR $\gamma \mathrm{KO}$ mice, display increased inflammatory cytokine production, resulting in a Th1-like inflammatory response supporting the critical role of PPAR $\gamma$ in lung homeostasis [26]. Furthermore, analysis of the MWCNT granuloma model in wild-type mice also revealed decreased PPAR $\gamma$ activity and expression in alveolar macrophages from MWCNT-instilled mice after 60 days [27]. Disruption of PPAR $\gamma$ occurs in several human lung diseases including sarcoidosis [28]. It should be noted that in sarcoidosis, PPAR $\gamma$ deficiency in BAL cells is characteristic of severe inflammatory pulmonary disease associated with deteriorating pulmonary function which requires systemic treatment [29]. Mean PPAR $\gamma$ levels in sarcoidosis patients classified as having non-severe pulmonary disease (which has a high chance of spontaneous resolution) do not differ from those of healthy controls [29].

Interferon-gamma is a hallmark cytokine of sarcoidosis [30-32]. PPAR $\gamma$ and IFN- $\gamma$ have demonstrated mutually antagonistic properties $[29,33]$. Furthermore, our previous in vitro studies with human alveolar macrophages demonstrated marked suppression of PPAR $\gamma$ by IFN- $\gamma$ treatment [29]. Taken together these studies suggest that the mechanisms of PPAR $\gamma$ suppression may involve IFN- $\gamma$. Further support of this concept is provided by our studies in MMP12 KO mice where reduction of IFN- $\gamma$ is accompanied by upregulation of PPAR $\gamma$ and granuloma resolution ([34], see Section 6. MMP12).

\subsection{PPAR $\gamma$ Deficiency and Elevated Granulomatosis}

In order to further define the role of PPAR $\gamma$ in granulomatous disease, we utilized macrophage-specific PPAR $\gamma \mathrm{KO}$ mice in an attempt to better elucidate pathways associated with sarcoidosis. The most striking feature in PPAR $\gamma \mathrm{KO}$ mice 60 days after oropharyngeal instillation of MWCNT was the presence of extensive granuloma formation within the lungs as assessed by histopathology and granuloma scoring indices compared to wild-type mice [27]. Furthermore, recruitment of increased CD3+ T cells to granulomatous foci in lungs was apparent by immunostaining [27]. Alveolar macrophages are the predominant cell type in BAL (93\% PPAR $\gamma$ KO versus $97 \%$ wild-type). BAL lymphocyte counts were also higher in PPAR $\gamma$ KO mice (7\%) than in wild-type (3\%) and were not changed with MWCNT instillation [27]. Moreover, compared to wild-type controls, BAL cells from PPAR $\gamma \mathrm{KO}$ control mice exhibited elevated expression of osteopontin and CCL2 (MCP-1) mediators, which were further increased by MWCNT instillation [27]. These findings indicated a tendency toward the elevation of inflammatory mediators in PPAR $\gamma \mathrm{KO}$ animals and suggested that $\operatorname{PPAR} \gamma$ might function as a negative regulator of granulomatous inflammation.

In a more recent study, we examined the effects of ligand-mediated activation of PPAR $\gamma$ in MWCNT-instilled wild-type mice [35]. Results indicated that activation of PPAR $\gamma$ via its specific ligand, rosiglitazone, inhibited granuloma formation, and reduced levels of the inflammatory mediators CCL2 and osteopontin via reduction of the proinflammatory transcription factor, NF- $\mathrm{kB}$ [35]. Both CCL2 and osteopontin expression are regulated by NF- $\kappa$ B activity $[36,37]$. These findings support the results of the previous study illustrating an exacerbation of inflammatory processes in PPAR $\gamma$ deficiency and significant negative regulatory effects of PPAR $\gamma$ on pulmonary granulomatous inflammation. 


\subsection{PPAR $\gamma$ Deficiency and Elevated Fibrosis}

As fibrosis is present in some $20 \%$ of sarcoidosis patients and is a leading cause of mortality [38], we investigated the possibility of fibrotic changes in MWCNT-instilled PPAR $\gamma$ $\mathrm{KO}$ mice $[39,40]$. We also added another experimental group to the model by including $20 \mu \mathrm{g}$ of ESAT-6, a 15-amino acid sequence of a mycobacterial antigen, in the instillation of MWCNT. Control groups received ESAT-6, MWCNT, or vehicle alone. The rationale for the ESAT- 6 study was based upon human studies citing ESAT- 6 as an inducer of T cell reactivity in sarcoidosis patients [41,42] as well as the suggestion that mycobacteria might constitute a causal element in the disease [43]. Moreover, the consequences of combining a microbial antigen within the MWCNT granuloma model had not been studied previously.

Initial experiments carried out in wild-type mice produced evidence that 60 days after concurrent instillation of the ESAT-6 peptide with MWCNT, both granulomatous involvement and pulmonary fibrosis had significantly increased compared to MWCNT instillation alone [39]. Interestingly, our previous studies in MWCNT-instilled wild-type mice had shown minimal evidence of fibrosis [12]. In ESAT-6/MWCNT instilled PPAR $\gamma$ $\mathrm{KO}$ mice, pathophysiology also increased in a similar fashion, with higher granuloma and fibrosis scores than with MWCNT alone [40]. Overall, granuloma and fibrosis pathology in ESAT-6/MWCNT instilled PPAR $\gamma$ KO mice exceeded values from wild-types [40]. The combination also elevated PPAR $\gamma \mathrm{KO}$ fibronectin gene expression in granuloma-negative areas of instilled lungs compared to MWCNT alone. Interestingly, expression of the inflammatory mediators, osteopontin and CCL2, was not further enhanced in PPAR $\gamma$ KO BAL cells after instillation of combined MWCNT/ESAT- 6 . In PPAR $\gamma$ KO but not wild-type BAL fluids, however, significant elevations of fibrosis mediator proteins TGF $\beta$, PDGFa, and IL-13 were found, suggesting that fibrotic pathways differed between wild-type and PPAR $\gamma \mathrm{KO}$ mice [40].

Due to the differences in wild-type and PPAR $\gamma \mathrm{KO}$ responses to ESAT- 6 inclusion in the MWCNT model, pulmonary retention of ESAT- 6 peptide in lung tissues was examined by mass spectrometry. Surprisingly, results indicated a lack of persistence of ESAT-6 in wild-type lungs at 60 days post instillation whereas ESAT-6 remained detectable in 60-day PPAR $\gamma$ KO lungs [40]. Such findings support previous data showing the capacity of PPAR $\gamma$ to enhance macrophage phagocytosis as part of a general resolution of inflammation [44]. Data further suggested that PPAR $\gamma$ deficiency might promote host reactivity to the antigenic ESAT-6 peptide via extended retention in tissue.

\subsection{PPAR $\gamma$ Deficiency and Elevated Th-17 Lymphocytes}

Our previous MWCNT instillation studies had noted elevated numbers of CD3+ T lymphocytes infiltrating pulmonary granulomatous areas in both wild-type and PPAR $\gamma$ KO mice [12,27]. Our most recent study explored the phenotypic characteristics of lymphocytes present in BAL fluids from PPAR $\gamma \mathrm{KO}$ and wild-type mice instilled with control (vehicle alone), MWCNT, or MWCNT + ESAT-6 [45]. As noted previously, PPAR $\gamma$ KO mice exhibited increased BAL lymphocytes compared to wild-type [26] but also showed elevated CD4/CD8 ratios [45]. BAL lymphocytes from MWCNT + ESAT-6 instilled wild-type and PPAR $\gamma$ KO mice all displayed elevated expression of the Thelper 1 (Th-1) transcription factor T-Bet, compared to controls. Unexpectedly, PPAR $\gamma$ KO BAL lymphocytes also exhibited increased markers of T Helper 17 (Th-17) cells compared to wild-type [45]. Current sarcoidosis studies show elevated Th-17 lymphocytes in both BAL fluids and peripheral blood from patients [32,46] and have proposed that Th-17 cells are necessary for promoting and reinforcing granuloma formation [47]. Such findings suggest links between PPAR $\gamma$ function, ESAT-6 stimulation, and T lymphocyte profiles which require further analyses in the MWCNT model.

\section{ABCG1 Deficiency}

Alveolar macrophage ATP-binding cassette $(\mathrm{ABC})$ transporters are critical to surfactant clearance and pulmonary lipid regulation [48,49]. In human disease, transporter 
deficiencies have been associated with Tangier disease (ABCA1) [48] and pulmonary alveolar proteinosis (ABCG1) [50]. In sarcoidosis, we have reported that both ABCA1 and ABCG1 transporters are deficient in alveolar macrophages [51]. Moreover, ABCG1 is deficient in untreated PPAR $\gamma \mathrm{KO}$ mice [52]. Further, we have noted that both ABCA1 and ABCG1 become decreased in both wild-type and PPAR $\gamma \mathrm{KO}$ murine alveolar macrophages at 60 days after MWCNT instillation [51].

\subsection{ABCG1 Deficiency and the MWCNT Granuloma Model}

Based on these findings, a further study was carried out to determine the effects of $A B C$ deficiencies in the MWCNT model [53]. Interestingly, results showed that deficiency of ABCA1 did not affect MWCNT-induced granuloma formation or pro-inflammatory gene expression. ABCG1 deficiency, however, clearly elevated pulmonary granulomatosis and fibrosis, as well as the expression of CCL2 and osteopontin mediators compared to wild-type mice [53]. These studies confirm the importance of intact PPAR $\gamma$ in regulating inflammatory disease as well as $A B C$ transporter levels. Exacerbation of pulmonary granulomatous changes and inflammation were promoted by deficiencies of either PPAR $\gamma$ or transporter ABCG1.

\subsection{ABCG1/ABCA1 Deficiencies and MicroRNA 33 Elevation in the MWCNT Model}

Further studies of the MWCNT model in both wild-type and PPAR $\gamma \mathrm{KO}$ mice revealed another regulatory pathway for ABC transporter control-that of microRNA 33 (miR33) [51]. Mir-33 is a recognized regulator of ABCA1 and ABCG1 lipid transporters [53]. In MWCNT-instilled mice (either wild-type or PPAR $\gamma \mathrm{KO}$ ) elevated miR-33 was detectable in BAL cells [51]. Baseline miR-33 values were higher in sham PPAR $\gamma \mathrm{KO}$ than wild-type, and MWCNT instillation elevated values in both strains. Concurrently, MWCNT instillation decreased levels of both $A B C A 1$ and $A B C G 1$ proteins in the lungs of both strains. In vitro studies confirmed that miR-33 overexpression induced decreases of both ABCA1 and ABCG1 gene expression in murine alveolar macrophages [51]. In vivo, elevated miR-33 expression was detected in granuloma but not non-granulomatous lung tissues in both wildtype and PPAR $\gamma \mathrm{KO}$ mice. Murine data mirrored results from human sarcoidosis patients where elevated miR-33 gene expression was present in both BAL cells and granuloma tissues found in mediastinal lymph nodes compared to control groups [51]. ABCA1 and ABCG1 gene and protein expression were also significantly decreased in BAL cells from sarcoidosis patients compared to healthy controls [51]. In conclusion, the results suggest two possible pathways for transporter dysregulation in granulomatous disease: the first associated with intrinsic PPAR $\gamma$ status, and the second with miR33 up-regulation triggered by environmental challenges, such as MWCNT.

\section{Common Gene Pathways in Sarcoidosis and the MWCNT Model}

To assess the possibility of similar pathway mechanisms in granulomatous inflammation, murine BAL samples from MWCNT-instilled and sham control animals were simultaneously analyzed with human BAL samples from sarcoidosis patients and healthy controls. Transcriptional profiles from the mouse model were compared to those from human samples to identify overlapping molecular programs [17]. To better define activated pathways, integrated network and gene set enrichment analyses (GSEA) were performed. Application of GSEA to both murine and human samples uncovered an upregulation of overlapping gene sets in mice and sarcoidosis patients that represented approximately $40 \%$ of the total sets. To analyze the global response of murine cells to MWCNT, correspondence analysis, a form of multidimensional scaling, was applied to the entire murine microarray data set. Results showed a clear separation between control and MWCNT-instilled mice with a majority of differentially expressed genes involved primarily in immunity and inflammation. Commonly activated processes in both MWCNT mice and sarcoidosis patients included adaptive immunity, T-cell signaling, interleukin (IL)-12 and IL-17 pathways, IFN- $\gamma$ signaling, apoptosis, and oxidative phosphorylation [17]. 
Quantitative PCR was used to validate four network genes identified as commonly upregulated in both the murine MWCNT model and in human sarcoidosis. Data confirmed elevated gene expression of MMP12, signal transducer and activator of transcription 4 (STAT4), cathepsin K (CTSK), and lymphocyte protein tyrosine kinase (LCK) [17]. These candidate genes are members of critical processes involved in lung remodeling and the immune response. For example, extracellular matrix-related gene products, including CTSK and MMP12, are critical to granuloma formation [34,54]. CTSK is one of a group of three related cysteine proteases which are present in the epithelioid and giant cells within granulomas [54]. Deficiencies of these proteases reduce the occurrence, composition, and formation of granulomas [54]. With respect to STAT4, activation is required in pathways leading to the expression of gamma interferon (IFN- $\gamma$ ) [55], a hallmark of inflammatory pathways in sarcoidosis [30].

\section{MMP12 Deficiency and the MWCNT Granuloma Model}

Our gene array studies on commonalities between the human sarcoidosis and murine MWCNT granuloma model showed that MMP12 was highly expressed in both species [17]. This suggested that MMP12 may be a key player for granuloma formation.

Initial studies of the MWCNT model noted a consistent elevation of the metalloproteinase, MMP12, in both granulomatous tissues and BAL cells of MWCNT-instilled mice [12]. MMP12 can be induced by the adhesion-promoting cytokine, osteopontin [56], which is also strongly elevated in MWCNT-instilled mice [12]. Previous studies have confirmed increased MMP12 gene and protein expression in sarcoidosis as well as the association of MMP12 elevation with disease severity [57]. To better understand the functions of MMP12, the MWCNT model was carried out in MMP-12 KO and wild-type mice [34]. Studies with MMP12 KO mice revealed acute reactions (10 days) similar to those of wild type. At chronic time points where wild-type maintained granulomatous disease (60 days), MMP12 KO mice exhibited attenuated granuloma formation as well as resolution, suggesting that MMP12 is necessary for granuloma progression. This coincided with elevated PPAR $\gamma$ and reduced IFN- $\gamma$ expression in BAL cells, suggesting that these mediators may also be involved since previous studies have shown that PPAR $\gamma$ suppresses IFN- $\gamma[29,33]$ and PPAR $\gamma$ deficiency amplifies granuloma formation [27]. These data strongly support a major role for MMP12 in granuloma formation and persistence.

\section{Summary and Conclusions}

A brief comparison of pulmonary mediator findings in the murine MWCNT model and in sarcoidosis patients indicates striking similarities between groups (Table 1). Among the elevated inflammatory mediators noted in both sarcoidosis and murine granuloma tissues were: osteopontin, MMP12, and the chemokine CCL2 (MCP-1) [12,57-59]. The presence of CD3+ T cells located in pulmonary granuloma foci from MWCNT-instilled mice was detected by immunostaining $[12,27,40]$. T cell accumulations in granulomatous tissues of sarcoidosis patients have also been consistently confirmed [47,60,61]. Moreover, comparative transcriptomics of MWCNT-instilled mice and sarcoidosis patients have indicated the presence of T cell signal transduction pathways within BAL cells [17] suggesting that, similar to sarcoidosis, the MWCNT model has an immune component. It should be noted again here that prominent deficiencies of the transcription factor, PPAR $\gamma$, and ABC transporters ABCA1 and ABCG1 have also been found in both the MWCNT model and sarcoidosis (Table 1, Figure 1). 
Table 1. Findings common to the MWCNT model and sarcoidosis.

\begin{tabular}{|c|c|c|c|}
\hline \multirow[t]{2}{*}{ Mediators and Status } & \multirow[t]{2}{*}{ Role in Pathophysiology } & \multicolumn{2}{|c|}{ Pulmonary Locations } \\
\hline & & MWCNT MODEL & SARCOIDOSIS \\
\hline $\begin{array}{l}\text { Peroxisome proliferator-activated } \\
\text { receptor gamma } \\
(\text { PPAR } \gamma) \text {-Deficiency }\end{array}$ & $\begin{array}{c}\text { Granuloma Formation [27] } \\
\text { Lipid Dysregulation [22] } \\
\text { Fibrosis [40] } \\
\text { Inflammatory Profiles [26] }\end{array}$ & $\begin{array}{l}\text { Bronchoalveolar lavage (BAL) } \\
\text { cells [27] }\end{array}$ & BAL cells [28] \\
\hline Osteopontin-Elevation & Granuloma Formation [18] & $\begin{array}{c}\text { Granuloma tissue, BAL cells, BAL } \\
\text { fluids }[12,62]\end{array}$ & Granuloma tissue [58] \\
\hline $\begin{array}{l}\text { Matrix-metalloproteinase } 12 \\
\text { (MMP-12)-Elevation }\end{array}$ & Granuloma Formation [34] & $\begin{array}{l}\text { Granuloma tissue, BAL cells (11) } \\
\text { [34] }\end{array}$ & Granuloma tissue, BAL cells [57] \\
\hline CCL2 (MCP-1)-Elevation & Granuloma Formation [63] & Granuloma tissue $[12,62]$ & Granuloma tissue [59] \\
\hline ABCG1-Deficiency & $\begin{array}{c}\text { Granuloma Formation [53] } \\
\text { Fibrosis [53] } \\
\text { Lipid Dysregulation [51] }\end{array}$ & BAL cells [51] & BAL cells [51] \\
\hline $\begin{array}{l}\text { Tumor Necrosis Factor alpha } \\
(\mathrm{TNF} \alpha) \text {-Elevation }\end{array}$ & $\begin{array}{l}\text { Macrophage M1 Inflammatory } \\
\text { Profile [64] }\end{array}$ & Granuloma tissue (11) & BAL cells [64] \\
\hline $\begin{array}{l}\text { Interferon-gamma } \\
\text { (IFN- } \gamma) \text {-Elevation }\end{array}$ & T Cell Inflammatory Profile [65] & Granuloma tissue, BAL cells [17] & BAL cells [30] \\
\hline $\begin{array}{c}\text { Signal Transducer and Activator } \\
\text { of Transcription (STAT } \\
\text { 4)-Elevation }\end{array}$ & T Cell Inflammatory Profile [55] & BAL cells [17] & BAL cells [17] \\
\hline Cathepsin K (CTSK)-Elevation & Granuloma Formation [54] & BAL cells [17] & BAL cells [17] \\
\hline TWIST 1-Elevation & $\begin{array}{l}\text { Macrophage M1 Inflammatory } \\
\text { Profile [60] }\end{array}$ & BAL cells [60] & BAL cells [60] \\
\hline \multirow{2}{*}{ Th17 cells-Elevation } & Inflammatory Profile [32] & \multirow{2}{*}{ BAL cells [45] } & \multirow{2}{*}{ BAL cells [32] } \\
\hline & Granuloma Formation [47] & & \\
\hline $\mathrm{T}$ cells-Elevation & Inflammatory Profile $[12,26]$ & Granuloma tissue $[27,40,45]$ & Granuloma tissue [47] \\
\hline ABCA1-Deficiency & Lipid Dysregulation [48] & BAL cells [51] & BAL cells [51] \\
\hline MicroRNA 33 (Mir-33)—Elevation & Lipid Dysregulation [66] & Granuloma tissue, BAL cells [51] & Granuloma tissue, BAL cells [51] \\
\hline
\end{tabular}

Pathways in the MWCNT Model

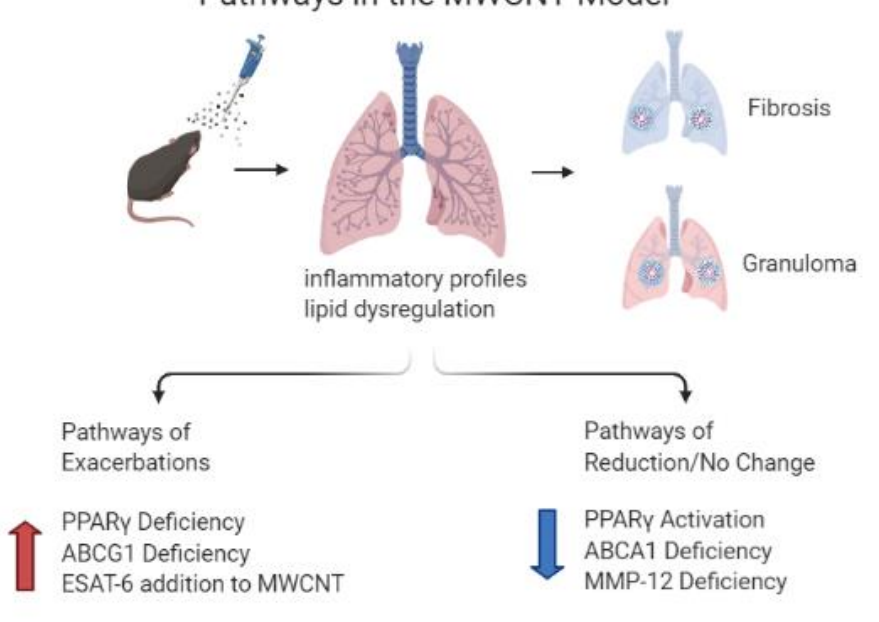

Created in BioRender.com bio

Figure 1. Schematic representation of proposed mechanisms affecting MWCNT-induced chronic granulomatous disease and fibrosis in mice. Mice instilled with MWCNT have an inflammatory response and lipid dysregulation. These lungs develop granulomas and depending on the challenge and strain may become fibrotic. Exacerbations are caused by deficiencies in PPAR $\gamma$, ABCG1 and addition of ESAT-6. Attenuation occurs with increased PPAR $\gamma$ activation, ABCA1 deficiency has no effect and MMP-12 deficiency results in reduction of granulomas. 
As noted in a recent review of in vitro/in vivo sarcoidosis models, more innovative approaches are needed to explore the pathogenesis and pathophysiology of sarcoidosis [67] A focus on granuloma formation alone is insufficient to provide information on mechanisms of fibrosis formation which affects some $20 \%$ of sarcoidosis patients [61]. Interestingly, the MWCNT model illustrates some fibrotic changes along with those relating to granuloma development but more so in some of the knock-out mouse strains, which may provide clues to pathogenic pathways. The representative histology of each of the mouse strains is shown in Figure 2. Wild-type (C57Bl /6) histology shows granuloma formation at 60 days with minimal fibrosis. PPAR $\gamma \mathrm{KO}$ and ABCG1 KO demonstrate prominent granulomatous and fibrotic inflammation. MMP $12 \mathrm{KO}$ show markedly attenuated granuloma formation and little fibrosis. Collectively, findings from the above MWCNT studies support usage of the MWCNT model as biologically relevant for sarcoidosis studies. The structure of the model is unique in that it provides a chronic inflammatory milieu lasting for 90 days. Comparative analyses have uncovered substantial pathway similarities between the MWCNT model and human sarcoidosis pathophysiology. Such results suggest that future exploration of novel therapeutics in sarcoidosis patients may benefit from utilizing the murine MWCNT model.

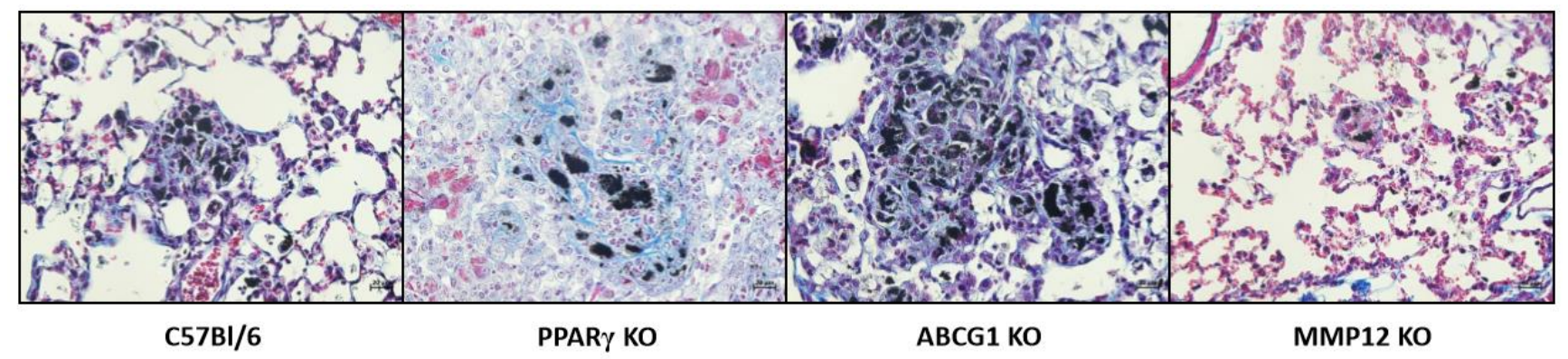

Figure 2. Representative trichrome staining from mice instilled with MWCNT for 60 days. Magnification 400X. C57Bl/6, ABCG1 KO, and MMP12 KO stained with Gomori's trichrome. PPAR $\gamma$ KO stained with Masson's trichrome.

Author Contributions: All authors contributed to the article equally and approved the submitted version. All authors have read and agreed to the published version of the manuscript.

Funding: This article was supported by NIH grant ES025191 to MJT and CHHE P30 ES025128.

Institutional Review Board Statement: Not applicable.

Informed Consent Statement: Not applicable.

Data Availability Statement: All data is publically available.

Conflicts of Interest: The authors declare that they have no known competing financial interest or personal relationships that could have appeared to influence the work reported in this paper.

\section{References}

1. Arkema, E.V.; Cozier, Y.C. Epidemiology of sarcoidosis: Current findings and future directions. Ther. Adv. Chronic Dis. 2018, 9, 227-240. [CrossRef] [PubMed]

2. Crouser, E.D.; Maier, L.A.; Wilson, K.C.; Bonham, C.A.; Morgenthau, A.S.; Patterson, K.C.; Abston, E.; Bernstein, R.C.; Blankstein, R.; Chen, E.S.; et al. Diagnosis and Detection of Sarcoidosis. An Official American Thoracic Society Clinical Practice Guideline. Am. J. Respir. Crit. Care Med. 2020, 201, e26-e51. [CrossRef]

3. Judson, M.A. Environmental Risk Factors for Sarcoidosis. Front. Immunol. 2020, 11, 1340. [CrossRef] [PubMed]

4. Culver, D.A.; Judson, M.A. New advances in the management of pulmonary sarcoidosis. BMJ 2019, 367, 15553. [CrossRef]

5. Newman, L.S.; Rose, C.S.; Bresnitz, E.A.; Rossman, M.D.; Barnard, J.; Frederick, M.; Terrin, M.L.; Weinberger, S.E.; Moller, D.R.; McLennan, G.; et al. A case control etiologic study of sarcoidosis: Environmental and occupational risk factors. Am. J. Respir. Crit. Care Med. 2004, 170, 1324-1330. [CrossRef] [PubMed]

6. Prezant, D.J.; Dhala, A.; Goldstein, A.; Janus, D.; Ortiz, F.; Aldrich, T.K.; Kelly, K.J. The incidence, prevalence, and severity of sarcoidosis in New York City firefighters. Chest 1999, 116, 1183-1193. [CrossRef] [PubMed] 
7. Crowley, L.E.; Herbert, R.; Moline, J.M.; Wallenstein, S.; Shukla, G.; Schechter, C.; Skloot, G.S.; Udasin, I.; Luft, B.J.; Harrison, D.; et al. "Sarcoid like" granulomatous pulmonary disease in World Trade Center disaster responders. Am. J. Ind. Med. 2011, 54, 175-184. [CrossRef] [PubMed]

8. Izbicki, G.; Chavko, R.; Banauch, G.I.; Weiden, M.D.; Berger, K.I.; Aldrich, T.K.; Hall, C.; Kelly, K.J.; Prezant, D.J. World Trade Center "Sarcoid-Like" Granulomatous Pulmonary Disease in New York City Fire Department Rescue Workers. Chest 2007, 131, 1414-1423. [CrossRef]

9. Sunil, V.R.; Radbel, J.; Hussain, S.; Vayas, K.N.; Cervelli, J.; Deen, M.; Kipen, H.; Udasin, I.; Laumbach, R.; Sunderram, J.; et al. Sarcoid-Like Granulomatous Disease: Pathologic Case Series in World Trade Center Dust Exposed Rescue and Recovery Workers. Int J. Environ. Res. Public Health 2019, 16, 815. [CrossRef]

10. Amenta, V.; Aschberger, K. Carbon nanotubes: Potential medical applications and safety concerns. Wiley Interdiscip. Rev. Nanomed. Nanobiotechnol. 2015, 7, 371-386. [CrossRef]

11. He, H.; Pham-Huy, L.A.; Dramou, P.; Xiao, D.; Zuo, P.; Pham-Huy, C. Carbon nanotubes: Applications in pharmacy and medicine. Biomed. Res. Int. 2013, 2013, 578290. [CrossRef] [PubMed]

12. Huizar, I.; Malur, A.; Midgette, Y.A.; Kukoly, C.; Chen, P.; Ke, P.C.; Podila, R.; Rao, A.M.; Wingard, C.J.; Dobbs, L.; et al. Novel Murine Model of Chronic Granulomatous Lung Inflammation Elicited by Carbon Nanotubes. Am. J. Respir. Cell Mol. Biol. 2011, 45, 858-866. [CrossRef] [PubMed]

13. Su, X.; Looney, M.; Robriquet, L.; Fang, X.; Matthay, M.A. Direct visual instillation as a method for efficient delivery of fluid into the distal airspaces of anesthetized mice. Exp. Lung Res. 2004, 30, 479-493. [CrossRef] [PubMed]

14. Li, J.-G.; Li, W.-L.; Xu, J.-Y.; Cai, X.-Q.; Liu, R.-L.; Li, Y.-J.; Zhao, Q.-F.; Li, Q.N. Comparative study of pathological lesions induced by multiwalled carbon nanotubes in lungs of mice by intrtracheal instillation and inhalation. Environ. Toxicol. 2007, 22, 415-421. [CrossRef]

15. Costa, D.L.; Lehmann, J.R.; Winsett, D.; Richards, J.; Ledbetter, A.D.; Dreher, K.L. Comparative pulmonary toxicological assessment of oil combustion particles following inhalation or instillation exposure. Toxicol. Sci. 2006, 91, 237-246. [CrossRef]

16. Driscoll, K.E.; Costa, D.L.; Hatch, G.; Henderson, R.; Oberdorster, G.; Salem, H.; Schlesinger, R.B. Intratracheal instillation as an exposure technique for the evaluation of respiratory tract toxicity: Uses and limitations. Toxicol. Sci. 2000, 55, 24-35. [CrossRef]

17. Mohan, A.; Malur, A.; McPeek, M.; Barna, B.P.; Schnapp, L.M.; Thomassen, M.J.; Gharib, S.A. Transcriptional survey of alveolar macrophages in a murine model of chronic granulomatous inflammation reveals common themes with human sarcoidosis. Am. J. Physiol. Lung Cell Mol. Physiol. 2018, 314, L617-L625. [CrossRef]

18. O’Regan, A.W.; Hayden, J.M.; Body, S.; Liaw, L.; Mulligan, N.; Goetschkes, M.; Berman, J.S. Abnormal pulmonary granuloma formation in osteopontin-deficient mice. Am. J. Respir. Crit. Care Med. 2001, 164, 2243-2247. [CrossRef]

19. Fingleton, B. Matrix metalloproteinases as regulators of inflammatory processes. Biochim. Biophys. Acta Mol. Cell Res. 2017, 1864, 2036-2042. [CrossRef]

20. Helming, L.; Gordon, S. The molecular basis of macrophage fusion. Immunobiology 2007, 212, 785-793. [CrossRef]

21. Tyagi, S.; Gupta, P.; Saini, A.S.; Kaushal, C.; Sharma, S. The peroxisome proliferator-activated receptor: A family of nuclear receptors role in various diseases. J. Adv. Pharm. Technol. Res. 2011, 2, 236-240. [CrossRef]

22. Straus, D.S.; Glass, C.K. Anti-inflammatory actions of PPAR ligands: New insights on cellular and molecular mechanisms. Trends Immunol. 2007, 28, 551-558. [CrossRef]

23. Smith, M.R.; Standiford, T.J.; Reddy, R.C. PPARs in alveolar macrophage biology. PPAR Res. 2007, 2007, 23812. [CrossRef] [PubMed]

24. Croasdell, A.; Duffney, P.F.; Kim, N.; Lacy, S.H.; Sime, P.J.; Phipps, R.P. PPARgamma and the Innate Immune System Mediate the Resolution of Inflammation. PPAR Res. 2015, 2015, 549691. [CrossRef]

25. Schachtrup, C.; Malcharek, S.; Haitsma, J.J.; Lachmann, B.; Owada, Y.; Binas, B.; Kondo, H.; Rustow, B.; Galla, H.J.; Spener, F. Activation of PPARgamma reverses a defect of surfactant synthesis in mice lacking two types of fatty acid binding protein. Biochim. Biophys. Acta 2008, 1781, 314-320. [CrossRef] [PubMed]

26. Malur, A.; Mccoy, A.J.; Arce, S.; Barna, B.P.; Kavuru, M.S.; Malur, A.G.; Thomassen, M.J. Deletion of PPARg in alveolar macrophages is associated with a Th-1 pulmonary inflammatory response. J. Immunol. 2009, 182, 5816-5822. [CrossRef] [PubMed]

27. Huizar, I.; Malur, A.; Patel, J.; McPeek, M.; Dobbs, L.; Wingard, C.; Barna, B.P.; Thomassen, M.J. The role of PPARgamma in carbon nanotube-elicited granulomatous lung inflammation. Respir. Res. 2013, 14, 7. [CrossRef] [PubMed]

28. Culver, D.A.; Barna, B.P.; Raychaudhuri, B.; Bonfield, T.L.; Abraham, S.; Malur, A.; Farver, C.F.; Kavuru, M.S.; Thomassen, M.J. Peroxisome proliferator-activated receptor gamma activity is deficient in alveolar macrophages in pulmonary sarcoidosis. Am. $J$. Respir. Cell Mol. Biol. 2004, 30, 1-5. [CrossRef]

29. Barna, B.P.; Culver, D.A.; Abraham, S.; Malur, A.; Bonfield, T.L.; John, N.; Farver, C.F.; Drazba, J.A.; Raychaudhuri, B.; Kavuru, M.S.; et al. Depressed peroxisome proliferator-activated receptor gamma (PPARgamma) is indicative of severe pulmonary sarcoidosis: Possible involvement of interferon gamma (IFN-gamma). Sarcoidosis. Vasc. Diffuse. Lung Dis. 2006, 23, 93-100. [PubMed]

30. Robinson, B.W.; McLemore, T.L.; Crystal, R.G. Gamma interferon is spontaneously released by alveolar macrophages and lung T lymphocytes in patients with pulmonary sarcoidosis. J. Clin. Investig. 1985, 75, 1488-1495. [CrossRef]

31. Asano, M.; Minagawa, T.; Ohmichi, M.; Hiraga, Y. Detection of endogenous cytokines in sera or in lymph nodes obtained from patients with sarcoidosis. Clin. Exp. Immunol. 1991, 84, 92-96. [CrossRef] [PubMed] 
32. Ramstein, J.; Broos, C.E.; Simpson, L.J.; Ansel, K.M.; Sun, S.A.; Ho, M.E.; Woodruff, P.G.; Bhakta, N.R.; Christian, L.; Nguyen, C.P.; et al. Interferon- $\gamma$-producing Th17.1 Cells are Increased in Sarcoidosis and More Prevalent Than Th1 Cells. Am. J. Respir. Crit. Care Med. 2016, 193, 1281-1291. [CrossRef] [PubMed]

33. Cunard, R.; Eto, Y.; Muljadi, J.T.; Glass, C.K.; Kelly, C.J.; Ricote, M. Repression of IFN-gamma expression by peroxisome proliferator-activated receptor gamma. J. Immunol. 2004, 172, 7530-7536. [CrossRef] [PubMed]

34. Mohan, A.; Neequaye, N.; Malur, A.; Soliman, E.; McPeek, M.; Leffler, N.; Ogburn, D.; Tokarz, D.A.; Knudson, W.; Gharib, S.A.; et al. Matrix Metalloproteinase-12 Is Required for Granuloma Progression. Front. Immunol. 2020, 11, 553949. [CrossRef]

35. McPeek, M.; Malur, A.; Tokarz, D.A.; Murray, G.; Barna, B.P.; Thomassen, M.J. PPAR-gamma pathways attenuate pulmonary granuloma formation in a carbon nanotube induced murine model of sarcoidosis. Biochem. Biophys. Res. Commun. 2018, 503, 684-690. [CrossRef] [PubMed]

36. Martin, T.; Cardarelli, P.M.; Parry, G.C.; Felts, K.A.; Cobb, R.R. Cytokine induction of monocyte chemoattractant protein-1 gene expression in human endothelial cells depends on the cooperative action of NF-kappa B and AP-1. Eur. J. Immunol. 1997, 27, 1091-1097. [CrossRef]

37. Zhao, W.; Wang, L.; Zhang, M.; Wang, P.; Zhang, L.; Yuan, C.; Qi, J.; Qiao, Y.; Kuo, P.C.; Gao, C. NF-kappaB- and AP-1-mediated DNA looping regulates osteopontin transcription in endotoxin-stimulated murine macrophages. J. Immunol. 2011, 186, 3173-3179. [CrossRef]

38. Bonham, C.A.; Strek, M.E.; Patterson, K.C. From granuloma to fibrosis: Sarcoidosis associated pulmonary fibrosis. Curr. Opin. Pulm. Med. 2016, 22, 484-491. [CrossRef]

39. Malur, A.; Barna, B.P.; Patel, J.; McPeek, M.; Wingard, C.J.; Dobbs, L.; Thomassen, M.J. Exposure to a Mycobacterial Antigen, ESAT-6, Exacerbates Granulomatous and Fibrotic Changes in a Multiwall Carbon Nanotube Model of Chronic Pulmonary Disease. J. Nanomed. Nanotechnol. 2015, 6, 340. [CrossRef]

40. Malur, A.; Mohan, A.; Barrington, R.A.; Leffler, N.; Malur, A.; Muller-Borer, B.; Murray, G.; Kew, K.; Zhou, C.; Russell, J.; et al. PPARgamma Deficiency Exacerbates Fibrotic Response to Mycobacteria Peptide in Murine Sarcoidosis Model. Am. J. Respir. Cell Mol. Biol. 2019. [CrossRef]

41. Carlisle, J.; Evans, W.; Hajizadeh, R.; Nadaf, M.; Shepherd, B.; Ott, R.D.; Richter, K.; Drake, W. Multiple Mycobacterium antigens induce interferon-gamma production from sarcoidosis peripheral blood mononuclear cells. Clin. Exp. Immunol. 2007, 150, 460-468. [CrossRef] [PubMed]

42. Drake, W.P.; Dhason, M.S.; Nadaf, M.; Shepherd, B.E.; Vadivelu, S.; Hajizadeh, R.; Newman, L.S.; Kalams, S.A. Cellular recognition of Mycobacterium tuberculosis ESAT-6 and KatG peptides in systemic sarcoidosis. Infect. Immun. 2007, 75, 527-530. [CrossRef] [PubMed]

43. Fang, C.; Huang, H.; Xu, Z. Immunolgical evidence for the role of mycobacteria in sarcoidosis: A meta-analysis. PLoS ONE 2016, 11, e0154716. [CrossRef] [PubMed]

44. Gautier, E.L.; Chow, A.; Spanbroek, R.; Marcelin, G.; Greter, M.; Jakubzick, C.; Bogunovic, M.; Leboeuf, M.; Van, R.N.; Habenicht, A.J.; et al. Systemic analysis of PPARgamma in mouse macrophage populations reveals marked diversity in expression with critical roles in resolution of inflammation and airway immunity. J. Immunol. 2012, 189, 2614-2624. [CrossRef] [PubMed]

45. Sanderford, V.; Barna, B.P.; Barrington, R.A.; Malur, A.; Mohan, A.; Leffler, N.; Soliman, E.; Thomassen, M.J. PPARgamma Deficiency in Carbon Nanotube-elicited Granulomatous Inflammation Promotes a Th17 Response to a Microbial Antigen. J. Nanomed. Nanotechnol. 2020, 11. [CrossRef]

46. Crouser, E.D. Role of imbalance between Th17 and regulatory T-cells in sarcoidosis. Curr. Opin. Pulm. Med. 2018, 24, 521-526. [CrossRef] [PubMed]

47. Bennett, D.; Bargagli, E.; Refini, R.M.; Rottoli, P. New concepts in the pathogenesis of sarcoidosis. Expert Rev. Respir. Med. 2019, 13, 981-991. [CrossRef] [PubMed]

48. Bates, S.R.; Tao, J.Q.; Collins, H.L.; Francone, O.L.; Rothblat, G.H. Pulmonary abnormalities due to ABCA1 deficiency in mice. AJP Lung Cell. Mol. Physiol. 2005, 289, L980-L989. [CrossRef]

49. Baldan, A.; Tarr, P.; Lee, R.; Edwards, P.A. ATP-binding cassette transporter G1 and lipid homeostasis. Curr. Opin. Lipidol. 2006, 17, 227-232. [CrossRef]

50. Thomassen, M.J.; Barna, B.P.; Malur, A.; Bonfield, T.L.; Farver, C.F.; Malur, A.; Dalrymple, H.; Kavuru, M.S.; Febbraio, M. ABCG1 is deficient in alveolar macrophages of GM-CSF knock-out mice and patients with pulmonary alveolar proteinsosis. J. Lipid Res. 2007, 48, 2762-2768. [CrossRef]

51. Barna, B.P.; McPeek, M.; Malur, A.; Fessler, M.B.; Wingard, C.J.; Dobbs, L.; Verbanac, K.M.; Bowling, M.; Judson, M.A.; Thomassen, M.J. Elevated MicroRNA-33 in Sarcoidosis and a Carbon Nanotube Model of Chronic Granulomatous Disease. Am. J. Respir. Cell Mol. Biol. 2016, 54, 865-871. [CrossRef] [PubMed]

52. Baker, A.D.; Malur, A.; Barna, B.P.; Ghosh, S.; Kavuru, M.S.; Malur, A.G.; Thomassen, M.J. Targeted PPAR\{gamma\} deficiency in alveolar macrophages disrupts surfactant catabolism. J. Lipid Res. 2010, 51, 1325-1331. [CrossRef] [PubMed]

53. McPeek, M.; Malur, A.; Tokarz, D.A.; Lertpiriyapong, K.; Gowdy, K.M.; Murray, G.; Wingard, C.J.; Fessler, M.B.; Barna, B.P.; Thomassen, M.J. Alveolar Macrophage ABCG1 Deficiency Promotes Pulmonary Granulomatous Inflammation. Am. J. Respir. Cell Mol. Biol. 2019, 61, 332-340. [CrossRef] [PubMed]

54. Samokhin, A.O.; Gauthier, J.Y.; Percival, M.D.; Bromme, D. Lack of cathepsin activities alter or prevent the development of lung granulomas in a mouse model of sarcoidosis. Respir. Res. 2011, 12, 13. [CrossRef] 
55. Nguyen, K.B.; Watford, W.T.; Salomon, R.; Hofmann, S.R.; Pien, G.C.; Morinobu, A.; Gadina, M.; O'Shea, J.J.; Biron, C.A. Critical role for STAT4 activation by type 1 interferons in the interferon-gamma response to viral infection. Science 2002, 297, $2063-2066$. [CrossRef]

56. O'Regan, A. The role of osteopontin in lung disease. Cytokine Growth Factor Rev. 2003, 14, 479-488. [CrossRef]

57. Crouser, E.D.; Culver, D.A.; Knox, K.S.; Julian, M.W.; Shao, G.; Abraham, S.; Liyanarachchi, S.; Macre, J.E.; Wewers, M.D.; Gavrilin, M.A.; et al. Gene Expression Profiling Identifies MMP-12 and ADAMDEC1 as Potential Pathogenic Mediators of Pulmonary Sarcoidosis. Am. J. Respir. Crit. Care Med. 2009, 179, 929-938. [CrossRef]

58. O'Regan, A.W.; Chupp, G.L.; Lowry, J.A.; Goetschkes, M.; Mulligan, N.; Berman, J.S. Osteopontin is associated with T cells in sacroid granulomas and has T cell adhesive and cytokin-like properties in vitro. J. Immunol. 1999, 162, $1024-1031$.

59. Palchevskiy, V.; Hashemi, N.; Weigt, S.S.; Xue, Y.Y.; Derhovanessian, A.; Keane, M.P.; Strieter, R.M.; Fishbein, M.C.; Deng, J.C.; Lynch, J.P., III; et al. Immune response CC chemokines CCL2 and CCL5 are associated with pulmonary sarcoidosis. Fibrogenesis. Tissue Repair. 2011, 4, 10. [CrossRef]

60. Barna, B.P.; Huizar, I.; Malur, A.; McPeek, M.; Marshall, I.; Jacob, M.; Dobbs, L.; Kavuru, M.S.; Thomassen, M.J. Carbon nanotubeinduced pulmonary granulomatous disease: Twist1 and alveolar macrophage m1 activation. Int. J. Mol. Sci. 2013, 14, 23858-23871. [CrossRef]

61. Patterson, K.C.; Chen, E.S. The Pathogenesis of Pulmonary Sarcoidosis and Implications for Treatment. Chest 2018, 153, 1432-1442. [CrossRef] [PubMed]

62. Wang, X.; Katwa, P.; Podila, R.; Chen, P.; Ke, P.C.; Rao, A.M.; Walters, D.M.; Wingard, C.J.; Brown, J.M. Multi-walled carbon nanotube instillation impairs pulmonary function in C57BL/6 mice. Part. Fibre. Toxicol. 2011, 8, 24. [CrossRef]

63. Lu, B.; Rutledge, B.J.; Gu, L.; Fiorillo, J.; Lukacs, N.W.; Kunkel, S.L.; North, R.; Gerard, C.; Rollins, B.J. Abnormalities in monocyte recruitment and cytokine expression in monocyte chemoattractant protein 1-deficient mice. J. Exp. Med. 1998, 187, 601-608. [CrossRef] [PubMed]

64. Fehrenbach, H.; Zissel, G.; Goldmann, T.; Tschernig, T.; Vollmer, E.; Pabst, R.; Muller-Quernheim, J. Alveolar macrophages are the main source for tumour necrosis factor-alpha in patients with sarcoidosis. Eur. Respir. J. 2003, 21, 421-428. [CrossRef] [PubMed]

65. Prasse, A.; Georges, C.G.; Biller, H.; Hamm, H.; Matthys, H.; Luttmann, W.; Virchow, J.C., Jr. Th1 cytokine pattern in sarcoidosis is expressed by bronchoalveolar CD4+ and CD8+ T cells. Clin. Exp. Immunol. 2000, 122, 241-248. [CrossRef]

66. Rayner, K.J.; Sheedy, F.J.; Esau, C.C.; Hussain, F.N.; Temel, R.E.; Parathath, S.; van Gils, J.M.; Rayner, A.J.; Chang, A.N.; Suarez, Y.; et al. Antagonism of miR-33 in mice promotes reverse cholesterol transport and regression of atherosclerosis. J. Clin. Investig. 2011, 121, 2921-2931. [CrossRef]

67. Besnard, V.; Jeny, F. Models Contribution to the Understanding of Sarcoidosis Pathogenesis: “Are There Good Models of Sarcoidosis?". J. Clin. Med. 2020, 9, 2445. [CrossRef] 